\author{
UDC 378.147: 37.018 .43 \\ Olena Rosynska, Halyna Horbenko, Oksana Zhuravska \\ Borys Grinchenko Kyiv University, Kyiv, Ukraine
}

\title{
RESEARCHING THE ASPECTS OF INTERACTION BETWEEN EDUCATORS AND STUDENTS IN THE DISTANCE LEARNING SYSTEM
}

\author{
DOI: $10.14308 /$ ite000731
}

Practical experience of distance learning in Institute of Journalism of Borys Grinchenko Kyiv University proves productivity of combining full-time and distance learning forms on the Moodle platform. The purpose of the research is to study how the Institute students and educators assess difficulties and achievements of distance learning, to analyze the differences and coincidences between the inquiries from students and educators, to establish Moodle-added platforms, suitable for all education process participants. The research studies the inquiries of students and educators in Institute of Journalism of Borys Grinchenko Kyiv University due to the change of an activity format during COVID-19 quarantine measures. 62 professors, 302 bachelors and masters have been inquired, as well as the participants' activity of internal distance learning system and the level of technical possibilities of access to it, utilization rate of platforms and services have been under analysis to receive the data. 1/3 of the respondents consider distance learning to be a critical need of that period, and more than 2/3 admit that it as a perspective learning form. $40 \%$ of educators regularly use distant technologies in their work and believe that the main problem is absence of face-to-face communication with students. More than $90 \%$ of students have an easy access to distance learning; moreover, poor Internet connection was specified as a problem for its implementation. Up to $70 \%$ of respondents consider the use of different learning platforms to be productive, a significant amount of them are video conference services. The monitoring provides grounds for further study of psychological needs for face-to-face communication, since the data received from the respondents demonstrate different approaches to this issue.

Keywords: distance learning, higher education, electronic academic course, online services

\section{Introduction}

Currently, a need to elucidate practical experience of introducing distance learning (DL) system has significantly grown up because all educational institutions have to develop a technology that assures a remote access to high quality education in the conditions of the quarantine restrictions or other cases of emergency.

Early publications devoted to DL focused predominantly on its so called blended form and a positive effect on educational process in general. Yoanny Beldarrain (2006) wrote about e-learning perspectives, which specified the creation of student-oriented environment using new technologies and instruments to stimulate cognitive activity, but at that time the share of Ukraine's Internet users amounted, according to different calculations, up to $10 \%$ of the population; that is why this did not entail full-fledge DL.

The work by O. Rafalska (2013) specified the peculiarities of the blended learning system, it said that "typical peculiarities of DL are: flexibility, modularity, parallelism, vast reach, economic efficiency, adaptability, social equality, internationality, a new role of a teacher, positive effect on a student, quality" (p. 109).

The experience of implementing DL is also one of fruitful themes that are elucidated in numerous publications of the Ukrainian scientists, particularly, let us pay attention to the monography of Information, Methodic and Organizational Assurance of Distance Learning (2013), 
which elucidates practice of spreading DL in the country. It is noticeable that the authors pay much attention to popularization of DL, first of all, destroying the myths wide-spread at that time concerning its unreliability, absence of proper control over the students' activity by educators, low quality of the knowledge received during distance course, etc. They also determine the categories of software solutions that assure functional possibilities for students and educators to work. However, the authors do not analyze the results of DL implementation or their qualitative assessment by the educational process participants, which, presumably, were not so important and topical at the time when that publication was prepared compared to nowadays when technical problems give place to methodic and psychological ones.

V. Kukharenko (2015) writes more about the development of the DL system in Ukraine. The author specifies that "currently web-resource has become a topical instrument of educational, scientific and economic activity in higher education institutions" (p. 54) and stresses that the use of modern information technologies allows universities and colleges to bear a severe competition at the educational services market.

Lorna R.Kearns's work (2016) is also useful for the research. It analyses the influence of experience of work with students on the Internet on teacher's thinking, planning academic activity, putting innovation into practice across delivery methods. The researcher is interested, first of all, in the quality of education, thus, she makes conclusions about a positive effect from IT use on educational process, particularly, part-time form of studying. Moreover, she notes that changes concern planning an academic course, students' activity and time usage during classroom training. According to Lorna R. Kearns, the use of the Internet allowed educators to focus more on the learning process rather than on teaching one. Besides, the difference between classroom and online training is gradually fading.

L. Halii and T. Seropian (2017) elucidate the peculiarities of a pedagogical experiment related to the implementation of DL to prepare specialists for the pharmaceutical industry. A slight amount of experiment participants (34 people) and blended learning forms (simultaneous lectures for full-time students; accomplishment of laboratory assignments and final tests during face-to-face meetings with educators, etc.) do not allow seeing whole amplitude of the DL issue to have emerged full blown under implementation of restrictive quarantine measures and is in the focus of the research offered.

A great interest in the context of our research is the review by Elsie Sophia Janse van Rensburg (2018). It analyses 47 publications devoted to the DL quality and classifies positive effects and challenges in the context of online-teaching and learning for educators and undergraduate students in health sciences. Thus, most researches specify a growing level of satisfaction and motivation among students; mastering skills in performance of tasks and solving current problems; flexibility of educational process and wider possibilities for building friendly academic environment; activation of students' cognitive activity; reduced gap between theory and practice; better proficiency in IT, etc. among positive results of online learning.

It is remarkable that the challenges are mostly technical (no Internet connection or its poor quality; low IT-competence of educational process participants (problem of selecting adequate services, resources or means helping to solve current educational tasks) or psychological ones (conditions for assurance of fast and effective feedback; issues of cooperation that arise due to the lack of face-to-face contact).

Let us note that the typology determined by the author can be used as a methodic scheme and applied taking into account bailiwick, particularly, to organize educational process in journalism. However, author does not clarify which exactly form of online learning the publications analyzed concerned - full complex or partially blended. Consequently, it is expected that unexpected and sudden shift to the form of DL specifies a range of additional challenges, which our research takes into consideration as it reflects the experience of exactly such organization of educational process. 
The review by A. Yilmaz \& P. Banyard (2020) where they analyse methods of engaging students in DL and offer own approaches to this process is helpful for our research.

Haruni Machumu and Chang Zhu (2019) write about the implementation of blended learning (online and full time) and formation of blended learning environment (BLE) based on constructivism in education. Let us note that constructivism as an educational psychology theory specifies that students build intensively the system of knowledge while performing practical assignments (Elliot, 2000). Although the experience described is specific because, first of all, constructivism-based learning was under analysis, its result can be useful for current Ukrainian pedagogical practice, which is also psychology-oriented in the educational process.

Scientific works of this year mostly focus on the issues caused by an unexpected shift to complex use of online-platforms, services, IT-instruments, as well as analyze challenges it caused, generally methodic and psychological ones. Publications about the educator's activity in the DL system devoted mostly to the issue of complex implementation of IT in practice of universities and colleges, search of new methods and approaches to work with students to form competences required for professional activity, assessment of education quality, etc., are also important in the context of our research.

Ganesh Kumar Nithyanandam (2020) describes the results of a pedagogical experiment, which comes down to the use in classes for bachelors and masters students of five methodologies, which are a free combination of different forms of work with students both using IT and without them, particularly, a visual representation of key information (mind maps), Open-Ended and Close-Ended Questions, Reflection, etc. In researcher's opinion, the use of these methods do not only increase academic progress but also forms Soft Skills required for successful employment.

The research by Shannon Skelcher (2020) is topical in this context; it is devoted to exactly psychological aspect of distance learning - ways and methods of forming and support of students' communication with the universities and colleges during the process. The scientist pays attention that as the students interview results showed, this connection is extremely low, however, based on the data received, she is able to find out and test some methods for its strengthening.

The situation caused by Covid-19 pandemic raised before the higher education new challenges which the education process participants had not seen before. First of all, one should take into account that learning and working in the DL system were not a free choice of a student and an educator, it became a working need specified particular peculiarities of the educational process and interaction between students and educators. Second, if before the educators and students worked mostly in the blended learning system, now they shifted to DL without options of choice. Thus, the research analyses readiness of all educational process participants for the DL system through the blended learning experience acquired before, their inquiries regarding the forms of the system use, their assessment of level of productivity of different platforms and instruments, as well as the system in general. Some aspects of this issue were elucidated to some extent before, but it was 2020 when there arose a need to analyze it from a new angle.

\section{Purpose of the study}

The purpose of the research is to study how the Institute students and educators assess difficulties and achievements of DL, to analyze the differences and coincidences between the inquiries from students and educators, to establish Moodle-added platforms, suitable for all education process participants. On one hand, that will help to implement optimum forms of cooperation if the quarantine measures are prolonged or in the event of a necessity for compulsory DL. On the other hand, the use of more flexible technologies in practice taking into account mutual expectations of educators and students will allow reception of higher level of study productivity and higher level of satisfaction from study with the use of distant technologies. 


\section{Method}

Practical experience of DL in Institute of Journalism of Borys Grinchenko Kyiv University proves productivity of combining full-time and DL forms on the Moodle platform. That allows permanent updating learning materials, using different forms of practical tasks performance, including additional resources for intensive cooperation with the group avoiding the issue or permanent knowledge deterioration especially in the fast developing areas, particularly, journalism and social communications.

The preparation of specialists, development of the skills required for work on different online-platforms by the institution educators are the fundamental basis for creating possibilities to implement DL in an educational institution. Particularly, any distance course user must have skills required to work on a computer, have an access to the Internet, skills of work online and required equipment for full-fledged learning and teaching are also obligatory.

The lecturing staff of Borys Grinchenko Kyiv University have powerful experience of so called "blended learning", which entails the performance of three-stage activity: "independent study of the material, a classroom interactive lesson, continued interactive study and support at the workplace" (Kukharenko, 2015), having assured, correspondingly, a required database for DL implementation at the educational institution.

\section{Participants}

While studying the efficiency of DL use within the quarantine period due to COVID-19 pandemic there was held a questionnaire among the full-time students of the first (bachelor) and second (master) educational levels. The students of 1-5 years majoring in 029 Information, Library and Archive Studies; 061 Journalism (academic programs of Journalism, Advertising and Public Relations; Publishing and Editing) studying in Institute of Journalism of Borys Grinchenko Kyiv University were questioned. Totally, 302 students became respondents. The questionnaire was held in March-May 2020 within the period of quarantine implementation.

Also, the educators of Institute of Journalism were inquired during the research. Totally, 62 full-time employees of the institution participated. For the practicing educators it is undeniable that pedagogic instruments required for the DL system are different from the ones for full-time or part-time learning. However, the educators in their activities orient on classic requirements of educational process, clearly determining the content of learning, competences being formed during disciplines studying, determining methods and forms of learning, learning instruments, etc.

\section{Data Collection and Analysis}

The questionnaire of the educational process participants who, on one hand, organized DL and on the other hand, received an educational service, provided a possibility for comprehensive study of the DL process under the conditions of quarantine restrictions

Simultaneously, the researchers were performing statistical analysis regarding the activity of students and educators within in the internal DL system as well as statistical analysis regarding the use of different online-platforms for distant classes.

The data received during the questionnaire and the statistical analysis values provide a possibility to make some theoretic generalizations regarding efficiency of DL practice in the higher education system having Institute of Journalism of Borys Grinchenko Kyiv University as an example. Questionnaire for the students and educators contained 14 and 16 obligatory questions correspondingly; they are detailed in Table 1. 
Examples of questions in the questionnaires for the students and educators

Students' questionnaire

\section{Respondents' demographic data}

e-mail, degree, year of studying, majoring in

\section{Educators' questionnaire}

\section{Multiple-choice questions}

- Do you use distance academic courses beyond the educational process in the University? (Yes, permanently/No, I don't /from time to time)

- What platforms do you consider the most productive for DL? Moodle/Zoom/Skype/Hangout meet/ I think it is reasonable to use different platforms in distance learning). This is a list of instruments the educators use the most often.

- How did your academic efficiency change during the DL? (increased/decreased/did not change)

- Is it important for you to have an available chat for permanent communication with an educator in the electronic academic course? (important/not important)
Do you consider DL technologies a promising direction of modern education? (it is a dictate of the time/it is one of learning forms/ it is unpromising).

- Do you take online courses to increase professional competence? (Yes, permanently/No, I don't/ from time to time)

- Have you taken a module on Information-Communication Technologies in the University? * (Yes/No/planned)

- Do you have certified EAC? **) Yes/No/submitted for certification)

- Which platforms for DL do you consider the most productive? (Moodle/Zoom/Skype/Hangouts meet/ I think it is reasonable to use different platforms in DL).

- How did your teaching productivity change during the quarantine learning? (efficiency increased/efficiency decreased/ efficiency did not change) 


\section{Multi-choice questions with an opportunity of providing own detailed answer:}

- Do you consider the DL technologies a promising direction? (it is a dictate of time/it is one of learning forms/it is unpromising/other)

- What is your experience in using DL forms? (have been using since the $1^{\text {st }}$ year permanently/using during the quarantine period/using during the current academic year/ other)

- In your opinion, a part teaching on online platforms providing face-to-face communication is (not important/ important as it provides an opportunity to discuss difficult issues/ possible but not obligatory/other)

- What problems impede you to study distantly? (poor connection/no required equipment and software/no face-to-face communication/ no team work/other)
- What is your experience of using DL forms? (permanent while teaching own disciplines/during the quarantine period/during current academic year/other)

- In your opinion, DL is efficient if (an educator works with students on one platform/an educator combines work on different platforms/other)

- In your opinion, part teaching on online-platforms providing face-to-face communication is (not important/important as that provides an opportunity to discuss complicated questions/possible but not obligatory/other)

- What problems impede your qualitative distant work? (poor connection/ no equipment and software, no face-to-face communication/other)

\section{Open questions specifying a detailed answer}

- What technologies, options and platforms could you offer to increase productivity of DL?
- What technologies, options or platforms could you offer to increase DL productivity?

- What factors make your work harder in DL mode?

- What, in your opinion, are DL advantages?

- What, in your opinion, are DL disadvantages?

Note * Module on ICT - special free courses to increase IT competence

Note ** Certificate confirming the academic course quality; it is subject to provision by special commission

Third, by monitoring the academic courses pages in internal learning system on the Moodle platform there were collected statistic data regarding technical possibilities of access to DL.

Further, there was performed a statistic and content analysis of replies. The conclusions under the research have been made using triangulation method that specifies consolidation and generalization of the data collected by different methods.

\section{Findings}

The respondents under the questionnaire indicate, particularly, that they think that the DL is: one of learning forms $(64.2 \%$ of students, $71 \%$ of educators $)$; a dictate of the times $(28.5 \%), 3.6 \%$ 50 
(11 respondents out of 302) believe that DL is unpromising. A part of respondents have selected an option "Other", one answer correspondingly: "I think that it is promising provided for appropriate implementation"; "I think it is a good impulse to modernize Ukraine's education"; "In my opinion, the majority of disciplines can be learnt remotely, I think it is a convenient form of learning"; "I think that the DL must be implemented when the institution is ready to implement it"; "I think it is a necessity during the quarantine"; "this is a form of learning of the 21 st century", etc. Thus, the majority of respondents assess positively the DL as a form of acquiring professional knowledge.

$40.3 \%$ of the educators inquired have specified that they permanently use DL instruments in their teaching activity, $43.5 \%$ use them permanently during the period under quarantine measures due to COVID-19 coronavirus pandemic, $11.3 \%$ use permanently during the current academic year.

An availability of Internet access and absence of other technical problems are important aspects for possible DL implementation. Table 2 demonstrates the statistics regarding an access of the educational process participants to DL during March-May 2020.

Table 2

Analysis of access level to the distance learning system

\begin{tabular}{lcccc}
\hline & $\mathrm{N}$ & $\%$ & $\mathrm{~N}$ & $\%$ \\
& student & & teachers & \\
\hline & 718 & $* 83$ & 76 & 100 \\
\hline Participate in distance learning & $\mathbf{7 1 8}$ & $\mathbf{1 0 0}$ & $\mathbf{7 6}$ & $\mathbf{1 0 0}$ \\
Do not have computers & 62 & 7 & 2 & 2,6 \\
Stay in residential areas where the Internet & 12 & 1,6 & 3 & 3,9 \\
connection is poor or absent & 30 & 4,1 & 3 & 3,9 \\
Other technical problems & 6 & 0,8 & 2 & 2,6 \\
Under medical treatment/chronic diseases & 3 & 0,4 & & 0 \\
Stay abroad & 2 & 0,2 & &
\end{tabular}

Note* except those who are on practical training, and part-time students who were not under the examination period

Table 2 demonstrates statistics regarding the involvement of Institute students and educators into DL and provides data about the factors that could become an obstacle for activity in the internal DL system. This analysis, performed in the beginning of the quarantine restrictions period allowed taking into account certain factors: particularly, students' possibility to be involved into the performance of tasks in the internal DL system at the time convenient for them, extension of deadlines for submission of the tasks fulfilled, involvement of mobile instruments for interaction of an educator and students. The Table 2 shows that among 865 students of the Institute, 718 participated in DL since 83 were on practice. Out of 718 students, 53 students - 7\% had circumstances impeding qualitative DL, however, $93 \%$ had possibilities for qualitative performance of DL.

This analysis, performed in the beginning of the quarantine measures implementation, allowed taking into account particular factors: particularly, an opportunity for an educator to receive a necessary technical support from the administration. The Table 2 shows that among 88 educators of the Institute only $10(11 \%)$ had circumstances impeding qualitative DL, instead $89 \%$ had possibilities for qualitative performance of DL.

Thus, the questionnaire demonstrates better readiness of educators to different forms of cooperation with students since it is a requirement of their professional activity, as well as it reveals a higher need for face-to-face interaction with the educational process participants. The issue requires an individual study as one of psychological pre-requisites of efficient learning. 
Picture 1 visualizes those factors, which educators and students specified as troubled ones while implementing DL, as these factors influenced, in their opinions, on the educational process quality and had to be taken into account in further work.

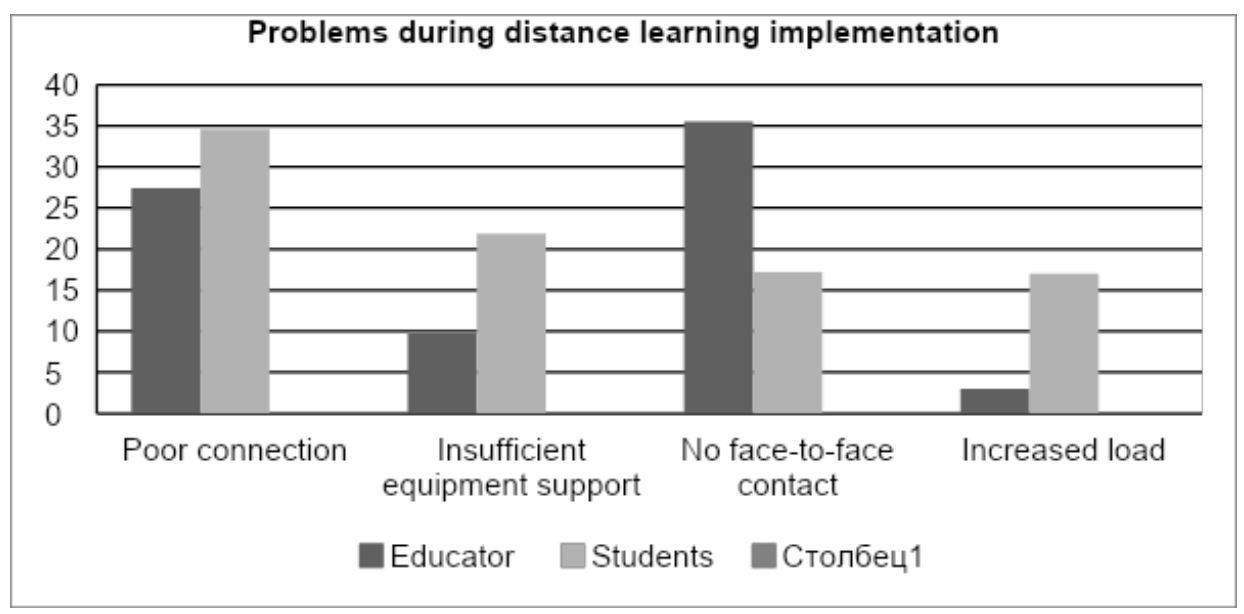

Picture 1. Problems of distance learning implementation for educators and students of Institute of Journalism of Borys Grinchenko Kyiv University (data of questionnaire in March-May, 2020)

The data provided demonstrate that the students mostly see the problems in poor connection, insufficient technical equipment and increased load, in a descending order. In the educators' opinion, the main problem impeding the qualitative learning is the absence of face-to-face communication with the students.

This value is quite important to understand the reasons that had to influence on the educational process in a distant form, since, on one hand, the students states a necessity for dynamic use of different platforms and, on the other hand, attached less significance to face-to-face communication with the educator.

The following answers were received to the question "Do you think it is required to hold a part of classes on online platforms, which provide face-to-face communication?":

- $\quad 74.2 \%$ of educators and $39.4 \%$ of students answered "important";

- $\quad 22.4 \%$ of educators and $51 \%$ of students answered "possible but not obligatory";

- $\quad$ no educators and $7.3 \%$ of students answered "not important".

A part of respondents, both among the educators and the students used an opportunity to answer at length:

- "depends on the discipline being taught";

- " "important but not always possible technically";

- $\quad$ "there must be video lectures with an opportunity to ask questions, and obligatory

chats in messengers where students can clarify an assignment during individual study";

- $\quad$ "important, especially for foreign language", etc.

Picture 2 provides an opportunity to compare the values of importance of face-to-face communication during education process for the Institute students and educators. The diagram shows that the educators lend more weight to immediate communication with the students in comparison with the students. This value requires deeper research to find out reasons and psychological-and-pedagogical aspects of the issue.

While working distantly, at the first stage the educators relied on the blended learning experience they received previously, which has been practiced in the educational institution for quite a long period. 


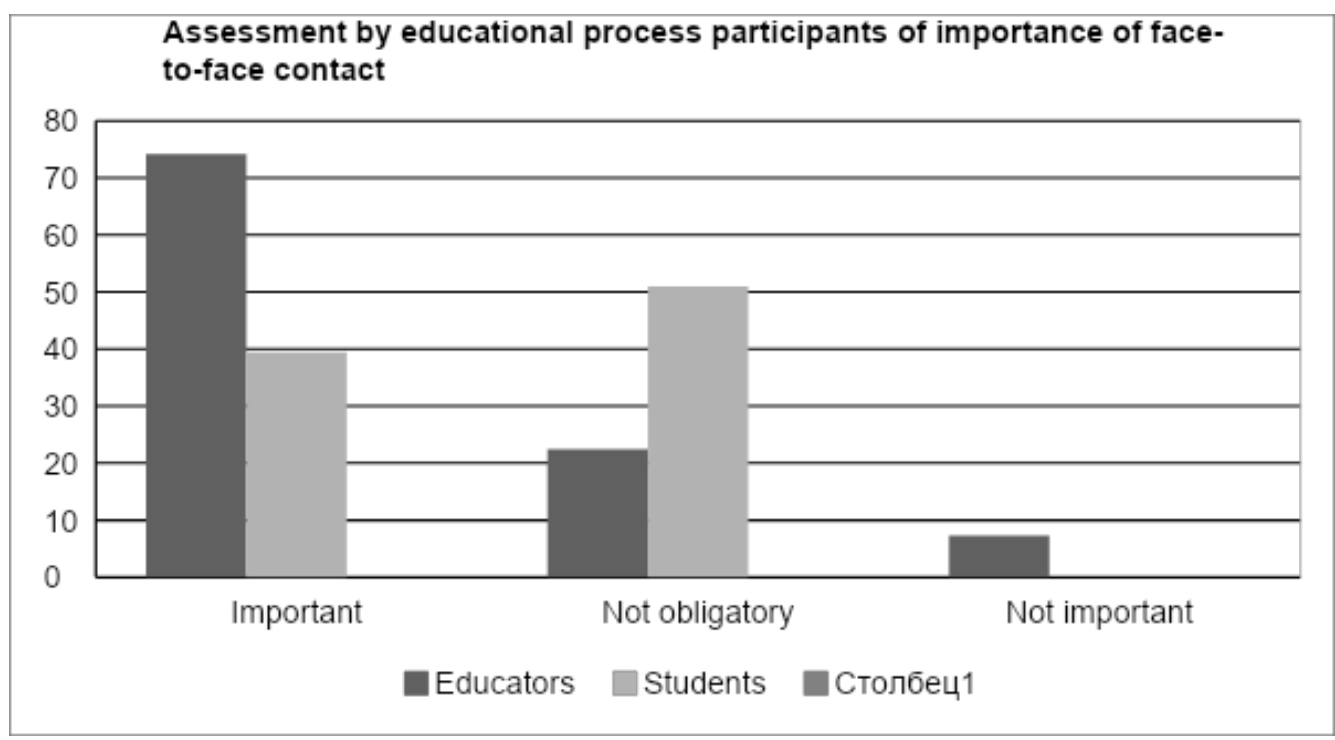

Picture 2. Assessment by educational process participants of face-to-face contact importance during distance learning (according to questionnaire in March-May, 2020)

The educators' experience in DL is an important aspect for educational process success because it allows taking into account students' needs. $53.2 \%$ of the educators occasionally take online courses to advance professional competence, $32.2 \%$ do that regularly, only $14.5 \%$ do not take such trainings. Hence, $85.5 \%$ of educators have experience of online learning, which enhances their ability to cooperate with the students since they acquire learning technologies, monitoring the troubled issues that may arise before students and prevent from them.

Thus, the experience of educators, on one hand, allowed them to get involved into the process quickly and, on the other hand, specified the use of standard forms of blended learning for the distant form, particularly, dominance of one platform where the tasks of electronic academic courses were placed.

For successful online learning, the students' experience became the same important. The students have sufficient experience of work in the DL system:

- $\quad 37.1 \%$ use permanently since they were 1 -year students

- $\quad 35.1 \%$ use during the quarantine period;

- $\quad 26.5 \%$ use during current academic year.

Some respondents have specified that they had experience of EACs use, but the intensity grew during the quarantine period. Thus, the students' experience in DL became one more reason for successful online-learning implementation.

To the question of "Do you study online beyond the educational process?" $50 \%$ of respondents answered "from time to time", 33.4\% answered negatively, $16.6 \%$ specified that they did that permanently. This value cannot be interpreted as the one that shows a low interest in regular online education, since that involves degree-seeking students involved into the educational process; instead, a need for additional training usually arises after the first graduation.

Table 3 demonstrates the availability of online and blended learning experience among educators and students 


\begin{tabular}{lcccc}
\multicolumn{5}{c}{ Experience of distance learning of teachers and students } \\
\hline & $\begin{array}{c}\mathrm{N} \\
\text { student }\end{array}$ & $\%$ & $\begin{array}{c}\mathrm{N} \\
\text { teachers }\end{array}$ & $\%$ \\
\hline & 302 & 100 & 62 & 100 \\
\hline $\begin{array}{l}\text { Distance learning experience } \\
\text { - enjoyed constantly }\end{array}$ & 113 & 37 & 25 & 40,3 \\
- enjoyed since the beginning of the & 80 & 26,5 & 7 & 11,3 \\
school year & 106 & 35,1 & 27 & 43,5 \\
- used during the quarantine period & & & & \\
\hline
\end{tabular}

Table 3 demonstrates that majority of the educators have already worked in the online education system either for a long time or during the academic year, that is why particular stereotypes regarding the organization of teaching prevailed.

The issue about IT-instruments that can be used, particularly, for preparing a media specialist becomes special because it does not only involve the use of technologies but also development of professional competence. The educational program for journalists' preparation of the first bachelor level specifies formation of such program educational results, as "Design personal projects to meet the needs of different types of media, explore effective journalistic methods of presenting information", "Create own multimedia products based on the application of information technologies learned", etc. (APP, 2017).

Moreover, two tendencies in educational process organization are seen: a tendency to use one platform or combination of different services and instruments. The analysis of the platforms and services applied to work with students majoring in journalism demonstrates quite a limited selection of them.Among seventy-six educators who were involved into the educational process during March-May 2020, the following tendency of using DL resources is traced: $55 \%$ of respondents use only Moodle, $40 \%$ - combine services; $5 \%$ - use video conference services. These data are provided in Picture 3.

Picture 3 shows that at a particular stage, the scheme of using online-platforms in practical work did not meet the inquiries from the educational process participants (as of the beginning of the period). The monitoring of the educational process demonstrates that the educators mainly used Moodle (84\%) since it provides methodic materials for educational courses developed in advance. Zoom (9\%), Hangouts Meet (5\%) and Google Class (2\%) were used less. Instead, the analysis of the students' inquiries after two weeks of implemented quarantine restrictions has demonstrated that online work of an educator and students using video platforms is psychologically important: owing to the effect of presence, favorable opportunities for thoughts exchange and emotional support are created. 


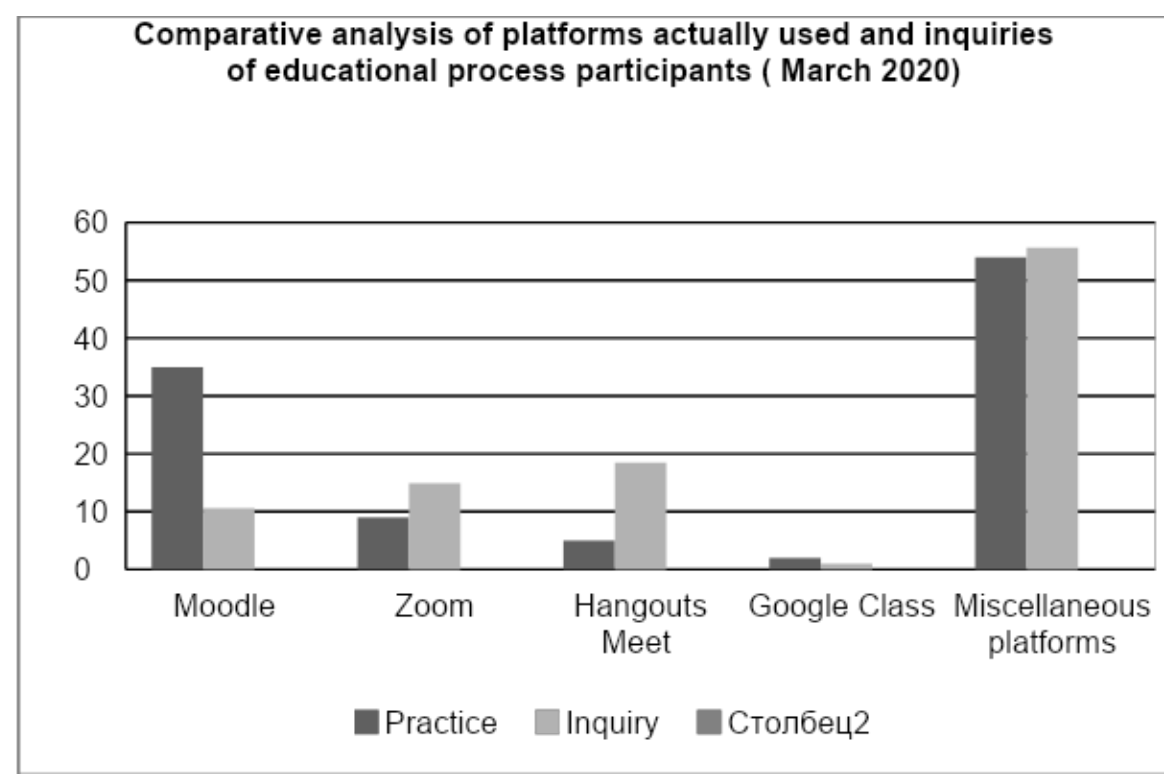

Picture 3. The use of online services in distance learning in Institute of Journalism of Borys Grinchenko Kyiv University (according to questionnaire in March 2020)

Picture 4 demonstrates the data representing the change of the situation concerning the use of platforms as of the end of the analyzed period. While implementing DL in May there was an equalization between practical use and inquiries through the research of possibilities of educators, students' requests, real efficiency of online-platforms compared to March 2020.

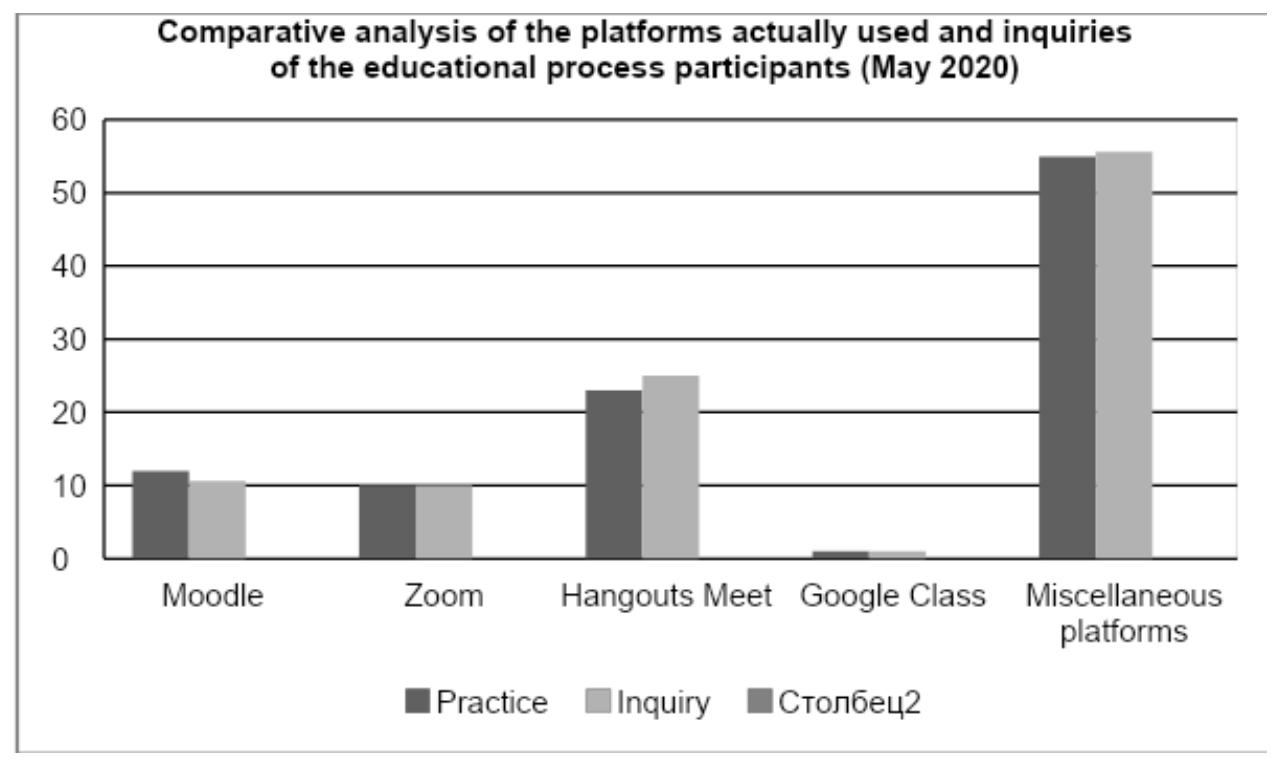

Picture 4. Tendencies of using distance learning resources among the educators of Institute of Journalism of Borys Grinchenko Kyiv University (according to data of the questionnaire in May 2020)

The questionnaire of Institute of Journalism educators shows that $69.4 \%$ of respondents consider work with students regarding different platforms use efficient: $9.7 \%$ prefer Hangouts Meet, $14.5 \%$ believe that Zoom meets the requirements of work, $4 \%$ are ready to work online on Moodle. 
Thus, it is noticeable that a number of educators tried to work in different systems involving both EACs resources and video conference format, which completely meets the requests from degree-seeking students:

- $\quad 55.6 \%$ of respondents think that the combination of possibilities provided by different platforms of distance cooperation between the educator and students is efficient;

- $\quad 18.5 \%$ prefer Hangouts meet platform;

- $\quad 14.9 \%$ consider efficient work in Zoom;

- $\quad 10.6 \%$ are ready to work only in Moodle system.

The results received meet the expectations completely because the participants of educational process in Borys Grinchenko Kyiv University have experience of harmonious combination of an immediate educator-student interaction and a distance form of work; thus, during absolute DL the students require immediate participation of the educator, face-to-face communication, and this request is completely understood by the educators.

Picture 5 shows gradual equation of the values regarding the students' inquiries concerning the use of online platforms and their actual use during the educational process.

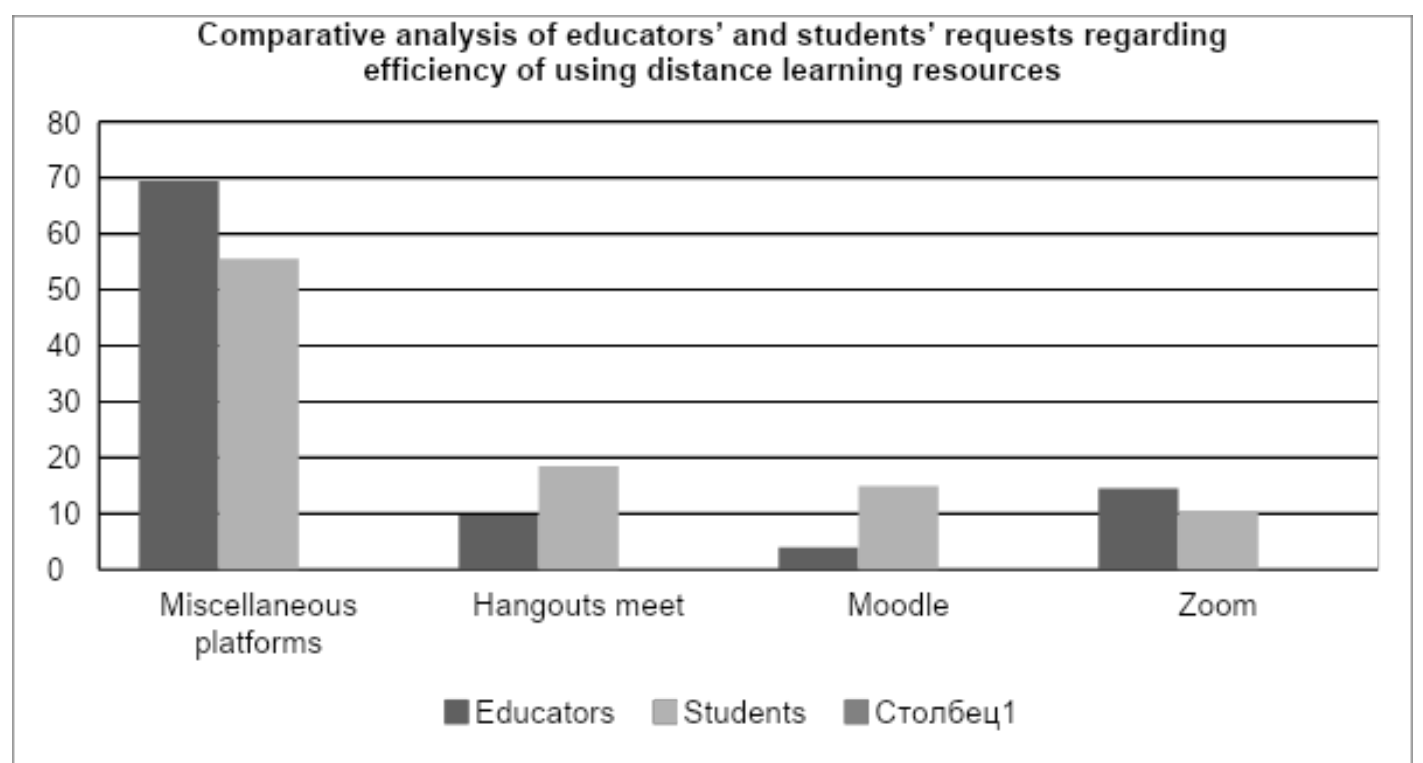

Picture 5. Comparative analysis of educators' and students' requests regarding efficiency of using distance learning resources in Institute of Journalism of Borys Grinchenko Kyiv University (according to the questionnaire in March-May 2020)

Thus, consideration of difference between the systems of blended and distance learning, as well as the analysis of the inquiries from the educational process participants and their positive experience provided an opportunity to change the model of interaction between the educators and students of the Institute.

Picture 6 demonstrates the assessment by the DL participants of dynamic in their work productivity. Education efficiency is an important value that demonstrates suitability of the implemented forms to study professional disciplines and to develop competences required. The students inquired from Institute of Journalism of Borys Grinchenko Kyiv University assess work efficiency as follows:

- $\quad$ efficiency increased $-32.3 \%$ of educators and $48.7 \%$ of the responding students;

- $\quad$ efficiency did not change $-61.3 \%$ of educators and $26.4 \%$ of students;

- $\quad$ efficiency decreased $-61.3 \%$ of educators and $24.8 \%$ (75) of students. 


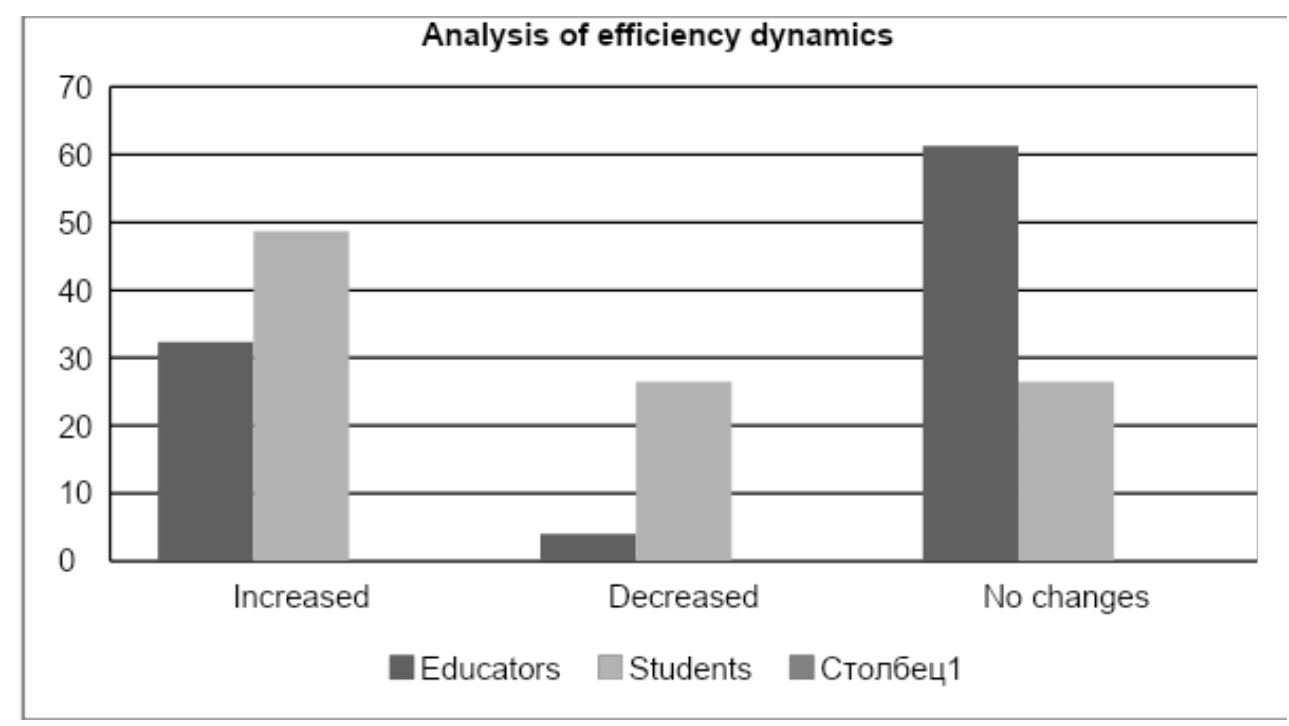

Picture 6. Dynamic productivity of distance learning (according to questionnaire in March-May, 2020)

Thus, the majority of the students questioned mention that their productivity increased, almost the equal amount specifies no changes or decrease in their productivity. These data require a study of different aspects when further research. The most of educators specify that the productivity of their work has not changed, which allows objecting a stereotype about excessive load on the educators during the DL, which is wide-spread in the national educational environment.

\section{Discussions and conclusion}

A professional prerequisite of efficient work is the understanding by all educational process participants of content, specific nature and assignments of DL. The goal-oriented preparatory work in the whole staff of Borys Grinchenko Kyiv University and Institute of Journalism as its individual subdivision, as well as previous experience of blended learning allowed decent response to the call of time and provided the students with a possibility to receive knowledge in an unusual educational process conditions at such a qualitative level as the higher education system requires.

The research performed demonstrates that practical DL implementation must be based on such determining principles as interactivity, flexibility, availability of feedback, individual learning.

The situation of practical DL implementation during March-May 2020 demonstrates a necessity to form pre-requisites for its implementation:

- $\quad$ creation by the educational institution of technical possibilities for DL;

- $\quad$ development of platforms for DL;

- $\quad$ ICT-training of educators;

- $\quad$ practical experience of partial DL use by all the educational process participants.

The research results indicate that the DL system must be used flexibly in specific conditions, in which, particularly, educational institutions of Ukraine appeared during the quarantine restrictions of March-May 2020; obligatory permanent monitoring of inquiries from educational process participants is important, the situations impeding the implementation of full-fledge learning are to be removed. The perspective of the research is to study teaching staff's experience within the DL period due to implementation of the quarantine measures in Ukraine, to analyze inquiries from educators as active participants and organizers of DL, to generalize administrative experience concerning the implementation of different DL forms.

The research proves no ground for a biased attitude to DL formed in the educational communities of the country since it demonstrates that this form of learning can be convenient and 
comfortable for all educational process participants in the event of a flexible approach to the use of opportunities provided by different platforms and allows saving or even increasing the productivity of the educational process.

\section{REFERENCES}

1. Beldarrain, Y. (2006). Distance Education Trends: Integrating New Technologies to Foster Student Interaction and Collaboration. Distance Education, 27 (2), 139-153. DOI: 10.1080/01587910600789498. Retrieved

from: https://www.tandfonline.com/doi/abs/10.1080/01587910600789498

2. Zuban, Yu., Liubchak, V., \& Ivanets, S. A. (2013). Informatsiine, metodychne ta orhanizatsiine zabezpechennia dystantsiinoho navchannia u vyshchykh navchalnykh zakladakh Ukrainy. [Information, Methodic and Organizational Assurance of Distance Learning]. Sumy: Sumy State University. Retrieved from: http://sumdu.edu.ua/int/images/docs/Study/GUIDELINES.pdf

3. Rafalska, O. (2013). Tekhnolohiia zmishanoho navchannia yak innovatsiia dystantsiinoi osvity [Blended learning technology as an innovation of distance education]. Computer-integrated technologies: education, science, production, 11, 129-133. Retrieved from: http://ki.lutsk-ntu.com.ua/node/127/section/22

4. Kukharenko, V. (2015). Systemnyi pidkhid do zmishanoho navchannia [A systematic approach to blended learning]. Information Technologies in Education, 24, 53-67. Retrieved from: http://www.irbis-nbuv.gov.ua/cgi-bin/irbis nbuv/cgiirbis_64.exe?I21DBN=LINK\&P21DBN=UJRN

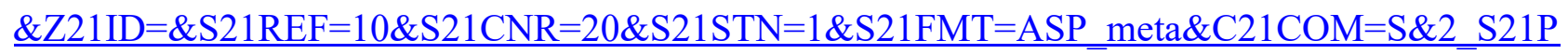
$\underline{03=F I L A=\& 2 \text { S21STR }=\text { itvo } 201524 \_6}$

5. Kearns, L. R. (2016). The Experience of Teaching Online and its Impact on Faculty Innovation across Delivery Methods. The Internet and Higher Education, 31 (October), 71-78. https://doi.org/10.1016/j.iheduc.2016.06.005. Retrieved from: https://www.researchgate.net/publication/304455102 The experience_of teaching_online_and_its impact on faculty innovation across delivery methods

6. Halii, L. \& Seropian, T. (2017). Vprovadzhennia dystantsiinoi formy navchannia u farmatsevtychnu osvitu [Introduction of distance learning in pharmaceutical education]. Pharmaceutical Review, 3, 112-117.

7. van Rensburg E. S. J. (2018). Effective online teaching and learning practices for undergraduate health sciences students: An integrative review. International Journal of Africa Nursing Sciences, 9, 73-80. https://doi.org/10.1016/j.ijans.2018.08.004.

8. Machumu, H., \& Zhu, Ch. (2019). Teachers' perceived roles and their constructivist engagement practices in blended learning environment courses in Tanzanian universities. International Journal of Learning Technology, 14 (2), 102-124. Retrieved from: http://www.irbis-nbuv.gov.ua/cgi-bin/irbis_nbuv/cgiirbis_64.exe?I21DBN=LINK\&P21DBN=UJRN

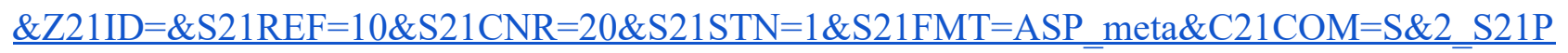

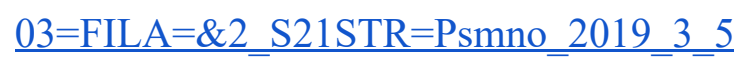

9. Elliott, S. N., Kratochwill, T. R., Littlefield Cook, J. \& Travers, J. (2000). Educational psychology: Effective teaching, effective learning (3rd ed.). Boston, MA: McGraw-Hill College. Retrieved from: https://files.eric.ed.gov/fulltext/EJ876482.pdf 
10. Shannon, S. (2020). Connecting Online Students to Their Higher Learning Institution. Journal Distance Education, 41 (1), 128-147. https://doi.org/10.1080/01587919.2020.1724771. Retrieved from: https://eric.ed.gov/?id=EJ1247974.

11. Nithyanandam, G. K. (2020). A Framework to Improve the Quality of Teaching-learning Process - A Case Study. Procedia Computer Science, 172, 92-97, https:/doi.org/10.1016/j.procs.2020.05.013. Retrieved from: https://www.researchgate.net/publication/342218119 A framework to improve the quality of te aching-learning process - A case study.

12. Academic professional program (APP). Kyiv., 2017. Retrieved from: https://kubg.edu.ua/images/stories/Departaments/vstupnikam/ij/2019/op_bach_journ_en-n.pdf

13. Yilmaz, A. \& Banyard, P. (2020). Engagement in Distance Education Settings: a Trend Analysis. Turkish Online Journal of Distance Education, 21 (1), 101-120. Retrieved from: https://www.researchgate.net/publication/338336010_Engagement_in_Distance_Education_Setting s A Trend Analysis

Росінська О.А., Горбенко Г. В., Журавська О. В.

Київський університет імені Бориса Грінченка, Київ, Україна ДОСЛІЖЕННЯ АСПЕКТІВ ВЗАСМОДІЇ ВИКЛАДАЧІВ ТА СТУДЕНТІВ У СИСТЕМІ ДИСТАНЦІЙНОГО НАВЧАННЯ

Практичний досвід дистанційного навчання в Інституті журналістики Київського університету імені Бориса Грінченка доводить ефективність поєднання форм денної та дистанційної форм навчання на платформі Moodle. Мета дослідження - вивчити, як студенти та викладачі Інституту оцінюють труднощі та здобутки дистанційного навчання, проаналізувати відмінності та збіги між запитами студентів і викладачів, створити додані Moodle платформи, придатні для всіх учасників освітнього процесу. У дослідженні вивчено запити студентів та викладачів Інституту журналістики Київського університету імені Бориса Грінченка у зв'язку зі зміною формату діяльності під час карантинних заходів через COVID-19. Було опитано 62 професори, 302 бакалаври та магістри, для отримання даних проаналізовано діяльність учасників внутрішньої системи дистанційного навчання та рівень технічних можливостей доступу до неї, коефіцієнт використання платформ та послуг. 1/3 респондентів вважають дистанційне навчання критичною потребою того періоду, а більше $2 / 3$ визнають, що це перспективна форма навчання. 40\% освітян регулярно використовують у своїй роботі віддалені технології і вважають, що основною проблемою є відсутність особистого спілкування зі студентами. Більше 90\% студентів мають легкий доступ до дистанційного навчання; більш того, погане підключення до Інтернету було визначено як проблему для його реалізації. До 70\% респондентів вважають використання різних навчальних платформ продуктивним, значна частина 3 них - послуги відеоконференцій. Моніторинг дає підстави для подальшого вивчення психологічних потреб у спілкуванні віч-на-віч, оскільки дані, отримані від респондентів, демонструють різні підходи до цього питання.

Ключові слова: дистанційне навчання, вища освіта, електронний академічний курс, онлайн-сервіси

Стаття надійшла до редакції 04.12.2020

The article was received 04 December 2020 